\title{
¿Cartografía del Nuevo Mundo, o la América Invisible?
}

\author{
Luis Andrés Valenzuela Olivares*
}

\begin{abstract}
Being the cartography represents the geographic environment, also is what manufactures our imaginary of the territory. That is why the author raises this representation to include and keep the Americas in the "maps of the world" of Cartography the New World, like the entrance towards the conquest and Westernization.

This article includes maps of the sixteenth century, to develop the study and the debate in the design and creation as control strategies, and of power addressed through cartographic silences, framing in the contradiction to magnify and conceal the existence of these new territories, both for their communities and for the enemies. Motives that are identified and molding spatial reality, defining the modern man.
\end{abstract}

Key words: Cartography and History, Strategies, Contradictions, Targets.

\section{Resumen}

Siendo la cartografía la que representa el entorno geográfico, es también, la que fabrica nuestro imaginario del territorio. Es por ello que el autor plantea esta representación de incluir y reservar el continente americano en los "mapamundis", la Cartografía del Nuevo Mundo, como la entrada hacia la conquista y la occidentalización.

En este artículo se incluyen mapas del siglo XVI, para desarrollar el estudio y el debate en su diseño y generación como en las estrategias de control y de poder, tratados a través de los silencios cartográficos, enmarcando en la contradicción de engrandecer y hasta ocultar la existencia de estos nuevos territorios, tanto para sus

* Cartógrafo y candidato a Magister en Historia, Facultad de Humanidades y Educación, Universidad Andrés Bello, Chile, correo electrónico: lvalenzuelaolivares@gmail.com 
comunidades como para los enemigos. Motivos que se identifican y que moldean la realidad espacial definiendo al hombre moderno.

Palabras clave: Cartografia e Historia, estrategias, contradicciones, objetivos.

\section{Introducción}

Desde tiempos inmemorables, la humanidad ha tratado de plasmar su entorno para brindar a su comunidad, amigos, colegas, compañeros, dueños, entre otros, el mundo que los rodea, su entorno. La Cartografía ha sido la ciencia y la herramienta con que se dispone para representar el espacio geográfico, a través de normas, que más que imitar el medio ambiente identifica patrones comunes que puedan ser entendibles para la mayoría de integrantes de la sociedad y por ende, su público. Esta sociedad expresará sus normas, según el medio, el lenguaje, sus creencias (la religión), percepciones y anhelos entre otros como la cultura que los identifica. En este sentido, la cartografía y con ella el mapa, ha facilitado el conocimiento del mundo y, configurado la interpretación del orbe.

Pero, ¿qué se sabía incuestionablemente del mundo? Para ello, hay que tener en cuenta a las comunicaciones, los dueños de la información y la distribución a los diferentes estamentos. Ya no cabe duda que la Tierra siempre fue considerada redonda, ${ }^{1}$ y que se sabía que existía una tierra que equilibraba las zonas conocidas. Aunque la tendencia hasta siglo $\mathrm{XV}^{2}$ fue colocarla en un disco ( $\mathrm{T}$ en $\mathrm{O}$ ) y orientarla a la divinidad (Figura 1), los eruditos y la clase dominante, estaban al tanto de la existencia del "otro continente". ¿Podemos hablar de Descubrimiento o depende desde qué punto de vista se dé el término? Si bien, la historia ha estado dada hacia la elite, a los acontecimientos importantes y a una larga duración, es parecer que el Descubrimiento de América como empresa y concepto, fue pensado tanto para el común de las personas como para los nativos de la nueva tierra, los subordinados de la Monarquía. En ellos, se educan y se someten a las ideas del vencedor, del patrón o encomendero y del clérigo, que si bien, el imaginario del Nuevo Mundo debía articular, la cartografía mental de los individuos también se debía de ocultar, ante los enemigos y a los intereses personales que se desarrollaban en las ideas de los notables. $^{3}$

Hay que tener en cuenta que la generación, producción, desarrollo y publicación de cartografía de la europea conquistadora estaba asociada a los hombres de poder, los que contaban con casas y escuelas de producción de cartografía, sin olvidar a la

1 El concepto de redondez de la Tierra ha ido cambiando gracias a los avances tecnológicos y a las ciencias geodésicas. Si para el siglo XV la Tierra se representaba en un disco, para el siglo XXI representa un geoide. Esta forma se asemeja más, ya que coincide con el nivel medio del mar.

2 Erwin Raisz, Cartografia General, trad. José Mantero, Barcelona, Omega, 1959, p. 26.

3 Este punto lo baso en las ideas de expansión territorial, que se incluyen dentro de la geopolítica para representar en los mapas los acuerdos y tratados de comercio, económicos y militares. 
Iglesia, que como organización política se dedicaba a la difusión y censura tanto de libros como de imágenes (en las que se incluían los mapas), desempeñando el papel de educadora de la población y que integraba en sus filas a los más ilustres cosmógrafos. La mayoría de ellos, de la orden jesuita, quedando dentro de las funciones de sus miembros, la estrategia militar, la gestión de las arcas y la confesión de las elites.

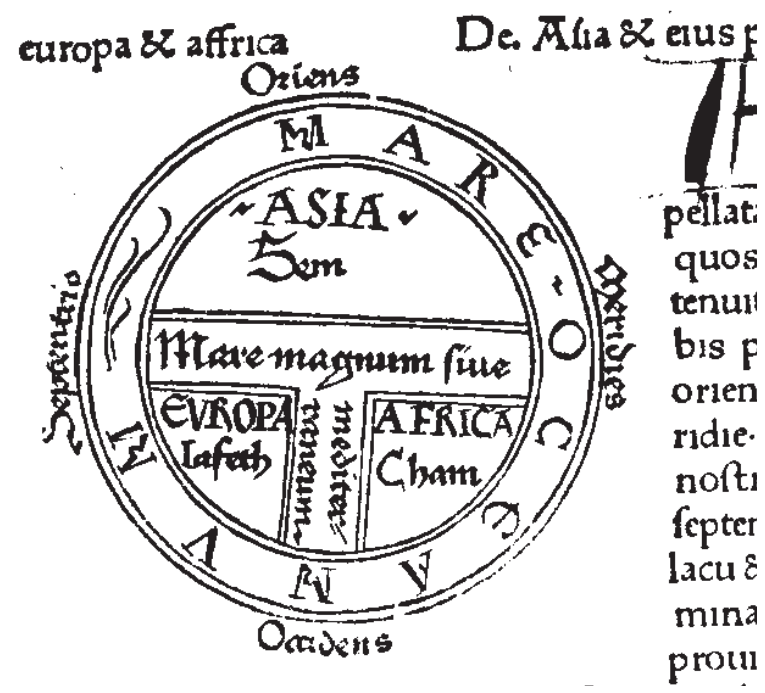

Figura 1. Günther Zainer, Etimologías de Isidoro de Sevilla (1472), Augsburgo. Esta representación de la Tierra muy común antes del siglo XV, podría corresponder más que indicar todo el mundo conocido, a una proyección Estereográfica. Representación impresa del mapa de $\mathrm{T}$ en $\mathrm{O}$, ilustrando la primera página del capítulo XIV, donde los continentes aparecen como dominios de los hijos de Noé: Sem (Sem), Iafeth (Jafet) y Cham (Cam).

Las cartografías que se publicaron del Nuevo Mundo como mapas, mapamundis, globos terráqueos, planos, entre otros, respondían a la solicitud y el gusto de los bienhechores, los que podían imprimir su sello y estampa a la interpretación y representación de la América Colonial. Muchas de las interpretaciones estaban basadas en cartas y relatos que llegaban desde las Indias y que respondían a la comunicación entre el receptor y emisor (sus mapas mentales), este imaginario lleva consigo elementos propios que "filtraban" la realidad conforme a sus condiciones culturales, económicas y fisiológicas. ${ }^{4}$

4 Jorge Espinoza, "Cartografía mental: una alternativa para la comprensión del comportamiento espacial del habitante urbano", Revista Trilogía, vol. 23, núm. 24, Santiago de Chile, 1995. También se puede revisar: Charles Taylor, Imaginarios sociales modernos, trad. Vilà Vernis, Ediciones Paidós, Barcelona, 2006. 
Si observamos esta "evolución" del Nuevo Mundo en el papel, ${ }^{5}$ y en especial los mapamundis, vemos que muchos de ellos, siguen una tendencia: por el eje central y por la incorporación del continente americano. Este último encontrado en diferentes proporciones (forma y superficie), ubicaciones y precisiones (Figuras 2 y 3 ). Por el contrario, existen otros — que han podido ser rescatados-, que demuestran una gran perfección tanto en la superficie como en la forma y el detalle que quieren representar (Figuras 4 y 5). Estos mapas afectan el modelo evolutivo de la cartografía y, nos hacen requerir una reinterpretación y discusión de los hechos.

Podemos definir que el territorio americano cumplía un propósito tanto para la Corona como para la Iglesia, una expansión a su política imperial de cristianización que se ve reflejada en ambas indias. ${ }^{6}$ Para los emigrantes ibéricos, América se basa - en especial- en transcender las fronteras, sus visiones e intereses, obtención de riquezas y tierras, (la tierra prometida, el sueño americano), ${ }^{7}$ lo que conlleva más que alumbrar el Nuevo Mundo a esconder este territorio, en parte por estrategias tanto políticas como militares, que identifican la abundancia de superficie como la supremacía respecto de las otras coronas, en oposición a disimular esta grandeza en la visión de occidente a los ultramarinos y a los propios peninsulares, la visión de la evolución del mundo en favor del poder y sometimiento de las masas, el pueblo. De esta manera, en este artículo, se tratan algunas causas que interfieren en la representación y con ella la interpretación del Nuevo Mundo, forjando en América, el continente imaginario más que el continente de las oportunidades, lo que se tradujo en una contradicción a la hora de representar a través de los trazos cartográficos el Nuevo Mundo. Hay que destacar, que en esta derivación que existen en expresar el poder político de expansión territorial y con ella el propósito a una globalización o mundialización también llamada "occidentalización" como lo menciona Miguel Ángel Cabrera, ${ }^{8}$ la cartografía nos favorece como herramienta de análisis e interpretación de la sociedad, donde se conjugan los pactos y secretos, los silencios de una época, intereses de poder, que interpretan las fronteras y territorios en el diseño del Nuevo Mundo. Como detalla Harley, "los silencios políticos de los mapas, tanto para mi interpretación de la naturaleza de la cartografía del Estado como para las diversas maneras en que los mapas se utilizaron para conservar y legitimar el poder

5 Los mapas confeccionados en el siglo XVI y XVII se realizaban a través de la impresión y el grabado en plancha de cobre o litografía.

6 Refiriendo al nombre que abarca a las Indias Orientales y las Indias Occidentales el Nuevo Mundo.

7 Hago una comparación contemporánea de lo que lo lleva a realizar esta expedición y/o emigrar, para la obtención de una mejor calidad de vida.

8 Dentro de la historiografías Cabrera realiza un ensayo epistemológico de cómo el mundo se occidentalizó. Miguel Ángel Cabrera, "La situación de la historia tras la crisis de la modernidad. Desafíos teóricos y epistemológicos", Seminario: Historiografia y tendencias en Historia Contemporánea: grandes maestros, nuevos valores, Universidad Internacional Menéndez Pelayo, España, 2008. 
del Estado", 9 expresión que más que definir un periodo específico al "Estado", se refiere a los que dominan y contienen el poder, siendo traducida a cualquier época en que se desarrolle una sociedad, sobre todo un imperio.

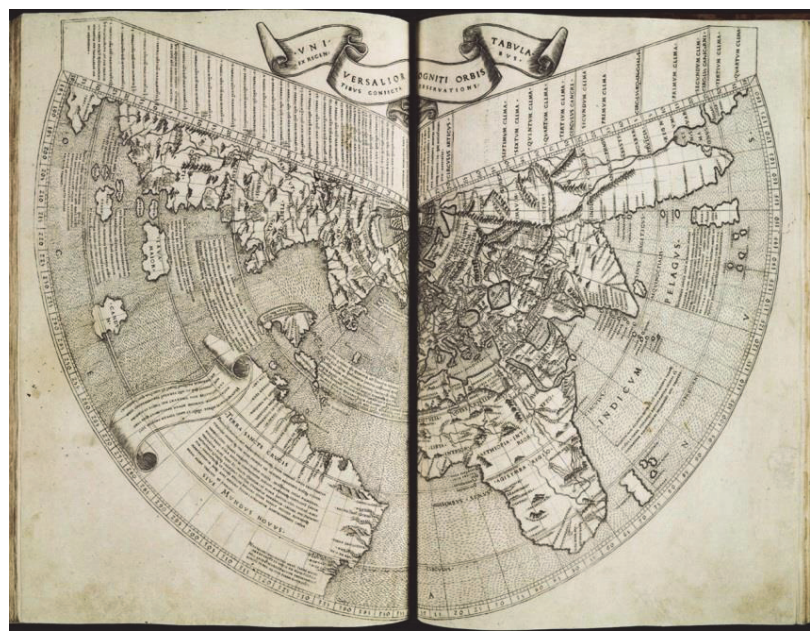

Figura 2. Johann Ruysch, Planisferio de Ruysch (1507). En este mapamundi, aunque su representación de América solo abarca los contornos del norte de Brasil manteniendo sus detalles, aumentando las superficies no conocidas.

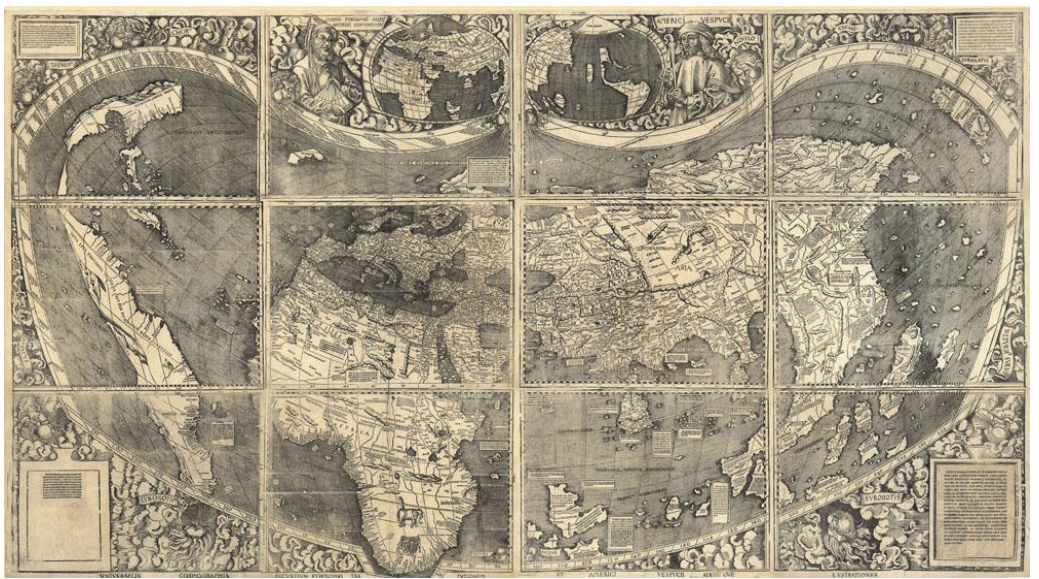

Figura 3. Waldseemüller, Universalis Cosmographia (1507). Aunque solamente se visualizan algunas islas de Centroamérica y parte de Brasil, este mapa ya incluía el continente Americano.

9 J.B. Harley, La nueva naturaleza de los mapas ensayos sobre la historia de la cartografia, trad. Leticia García, Juan Rodríguez, México, Fondo de Cultura Económica, 2005, p. 115. 


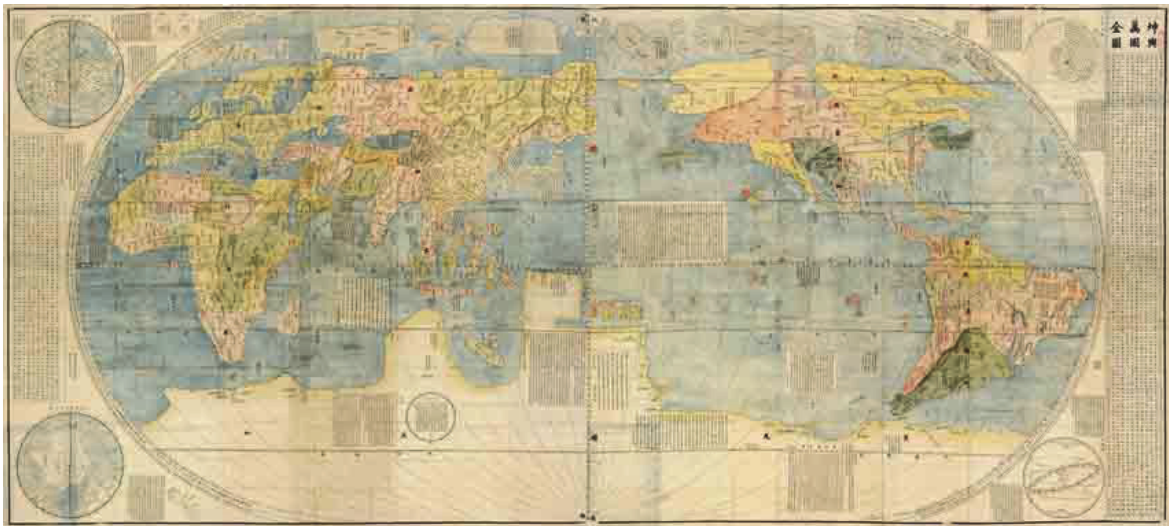

Figura 4. Matteo Ricci, Kunyu Wanguo Quantu (1602). Este mapa representa todo el mundo, con el eje de visión colocado en el Océano Pacifico. Copia japonesa a color de 1604 .

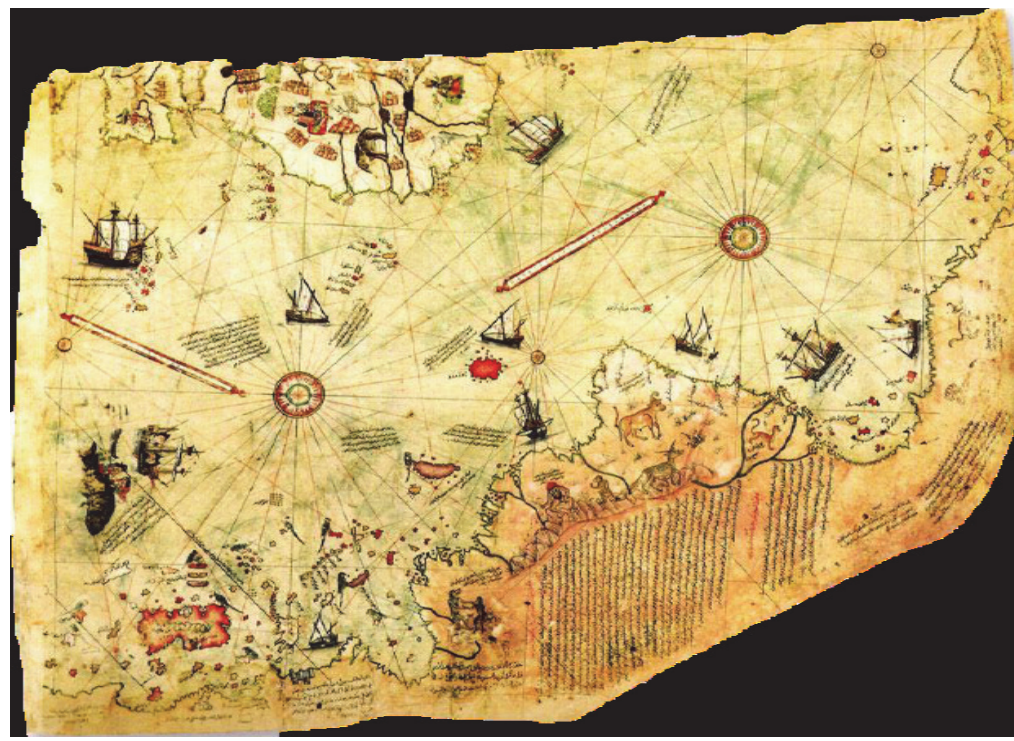

Figura 5. The Piris Rei Map (1513). Mapa que representa todo el contorno de América Central y Sur, agregando las tierras congeladas de la Antártida. Este mapa abre las interrogantes que ya se conocía América antes del descubrimiento y que no solamente les importó a los occidentales, sino que también al imperio otomano. Cabe señalar que la orientación del mapa cambia respecto a la cultura y las costumbres que norman sus representaciones. 


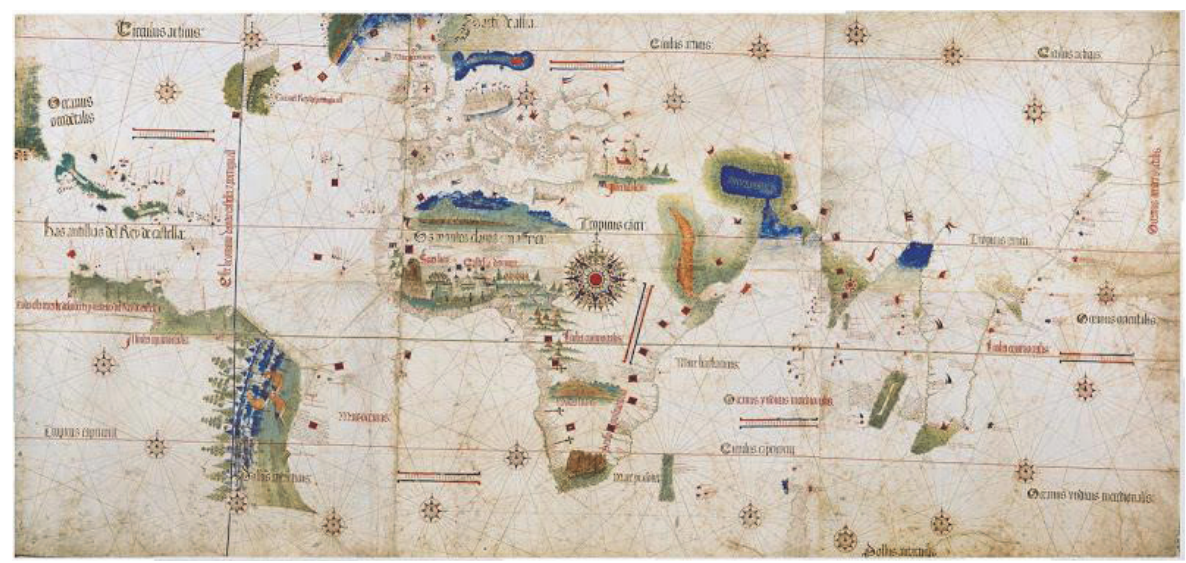

Figura 6. Alberto Cantino, Planisferio de Cantino (1502), Bibliothèque et Archives Nationales du Québec. Mapamundi donde se visualiza el meridiano situado 370 leguas al oeste de las islas de Cabo Verde a fin de evitar conflictos de intereses entre la Monarquía Hispánica y el reino de Portugal.

\section{América, la tierra escondida}

Desde un comienzo, a América se le ha nombrado de diferentes formas, dentro de ellas, algunas referidas al continente perdido de la Atlántida, ${ }^{10}$ otras como la Tierra Inhóspita, el Nuevo Mundo. Pero, ¿qué nos muestran los mapas de este Nuevo Mundo? Si realizamos un análisis descriptivo de las representaciones antes y durante el siglo XVI, encontramos muchas diferencias, a veces atribuidas hasta al mismo cartógrafo o cosmógrafo.

En el Descubrimiento y Conquista de América, las cartografías nos muestran disímiles formas, tanto del contorno del continente como de los detalles que incorporan. Entre las muchas diferencias encontramos: el ocultamiento de tierras, nombres (toponimia), la generación de espacios ficticios, proyecciones, hasta la introducción de la leyenda y el folclore. ${ }^{11}$ Silencios que impiden distinguir un desarrollo armónico de la ciencia cartográfica pero que facilitan el estudio y análisis histórico. Como menciona García, al considerar a los mapas como textos, más que solo imágenes, "se deben utilizar como complejas construcciones sociales, que demuestran un discurso prefabricado, lógico o imaginario". ${ }^{12}$

10 En los siglos XVI y XVII hubieron algunos cosmógrafos que utilizaron en sus mapamundis la definición de Atlántida para la América. Entre ellos están: Sebastián Münster, Map of América (1561), Nicolas Sanson, Atlantis Insula (1670).

11 Carmen Bernand y Serge Gruzinski, Historia del Nuevo Mundo: del descubrimiento a la conquista. La experiencia europea 1492-1550, México, Fondo de Cultura Económica, 1996, pp. 91-94.

12 Irma García Roja, "El estudio histórico de la cartografía”, Takwa, núm. 13, primavera 2008, p. 27. 


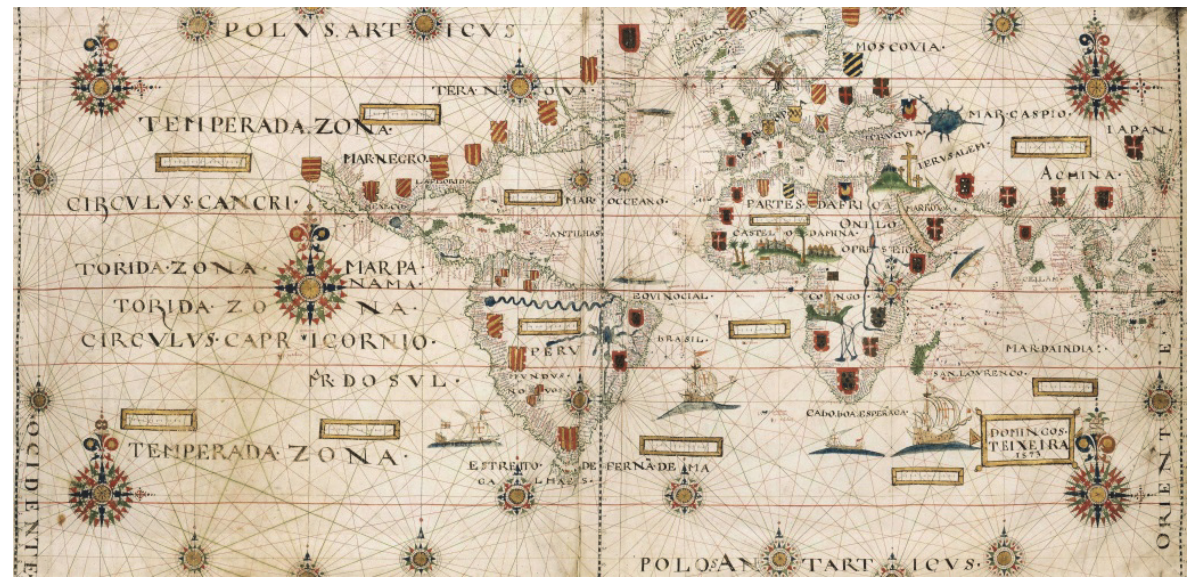

Figura 7. Domingos Teixeira, Mapamundi de Domingos Teixeira (1573), Bibliothèque National de France. Otro planisferio que muestra el meridiano del Tratado de Tordesillas.

Si la cartografía se basa en propósitos para su construcción y elaboración, ¿cuáles eran las causas para ocultar el territorio americano o engrandecerlo? ¿Por qué ocurre esta contradicción? ¿Desconocimiento? ¿Intereses locales? Dentro de los diferentes motivos que se dan en el siglo XVI y parte del XVII se pueden registrar dos grandes propósitos:

1. Estrategias de expansión territorial

2. Hegemonía política y religiosa

\section{Estrategias de expansión territorial}

Si nos remontamos al Descubrimiento de América, para nosotros es una fecha importante por el encuentro entre dos culturas. Por el contrario, para 1492 no fue de tanta relevancia. ${ }^{13}$ Aunque existen varias hipótesis de que el Nuevo Mundo ya se conocía y ya se había explorado. Lo que nos concierne son los motivos por los cuales la monarquía hispana y también la portuguesa encontraron especial interés para integrar a sus reinos, y ocultando a sus comunidades y a su oponente político las nuevas superficies territoriales. Un doble discurso, transformado en leyendas para el común, gracias a las distorsiones que generaba el imaginario de la distancia, y que el enemigo debía observar poco interés las nuevas tierras encontradas. Ejemplos que se remontan desde los primeros tratados hasta el Tratado de Tordesillas 
(1494) - para concluir con el dominio español sobre la corona de Portugal ${ }^{14}$ (1580)—, que llevaron a modificar los límites —en especial el meridiano-, según el reino de turno (Figuras 6 y 7). Otros pasan a enfocar al Nuevo Mundo como el lugar de exclusión de la población, dado por la deportación de habitantes de la península ibérica que llegó a cumplir las condenas delictivas en las Indias, algunos en Brasil otros en las Filipinas. ${ }^{15}$

La expansión se define como la incorporación y anexión de diferentes territorios. Como ya se tenían, la estrategia fue ocultarlo por aspectos militares y/o económicos. No hay que olvidar que la búsqueda de Colón fue encontrar un atajo a las especies (pimienta, azafrán almizcle y canela), factores comerciales que producían y daban el pie para hacer de estos viajes una empresa común y no desechable. Si bien los viajes podían durar meses —aunque a veces podían ocurrir desgracias-, los viajes a las Indias se hicieron tan comunes que la demanda de mapas a las escuelas cartográficas fue en aumento, disminuyendo en su calidad. Esto dependía tanto del control centralista de la monarquía como del contrabando de información e interpretación de la geografía nativa. En este sentido, los mapas representaban la solicitud de qué se publicaba y para quién se publicaba.

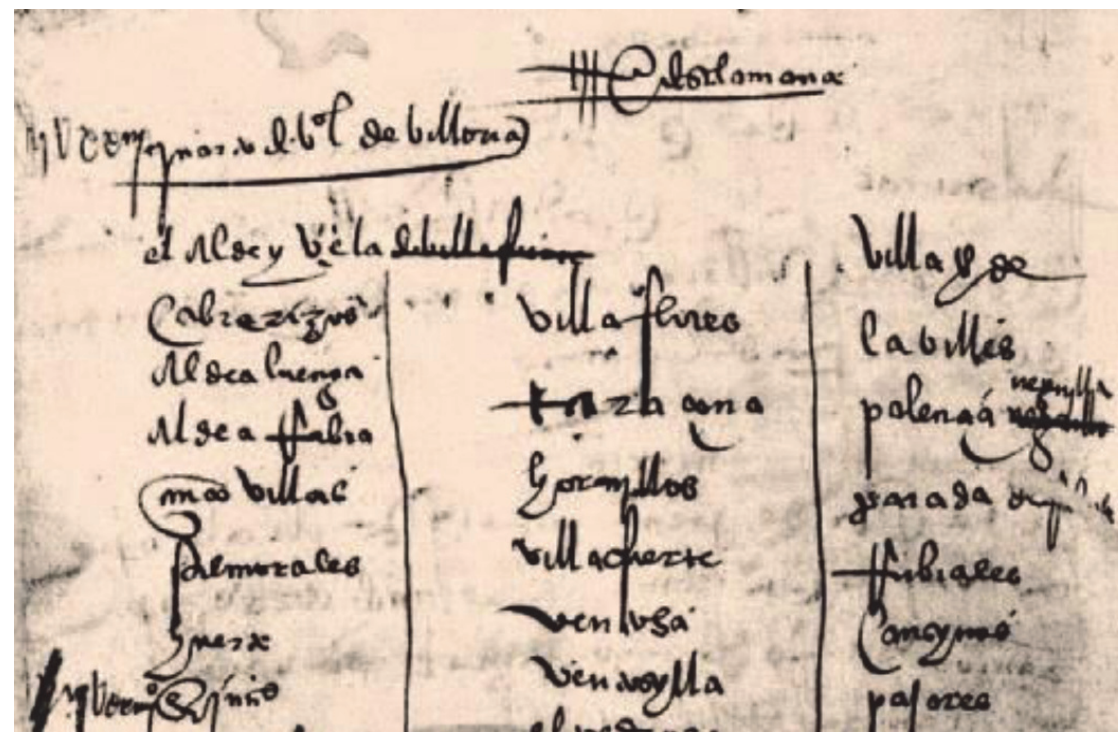

Figura 8. Hernando Colón, Itinerario (1517). Detalle listado de lugares de Castilla entre las descripciones de la Biblioteca Colombina del autor.

14 Después de la autoproclamación a la corona de Portugal por Antonio Prior de Crato, se libró la batalla de Alcántara (1580), tras la victoria de España, Felipe II fue proclamado rey de Portugal.

15 Serge Gruzinski, Las cuatro partes del mundo. Historia de una mundialización, México, Fondo de Cultura Económica, 2010, p. 116. 


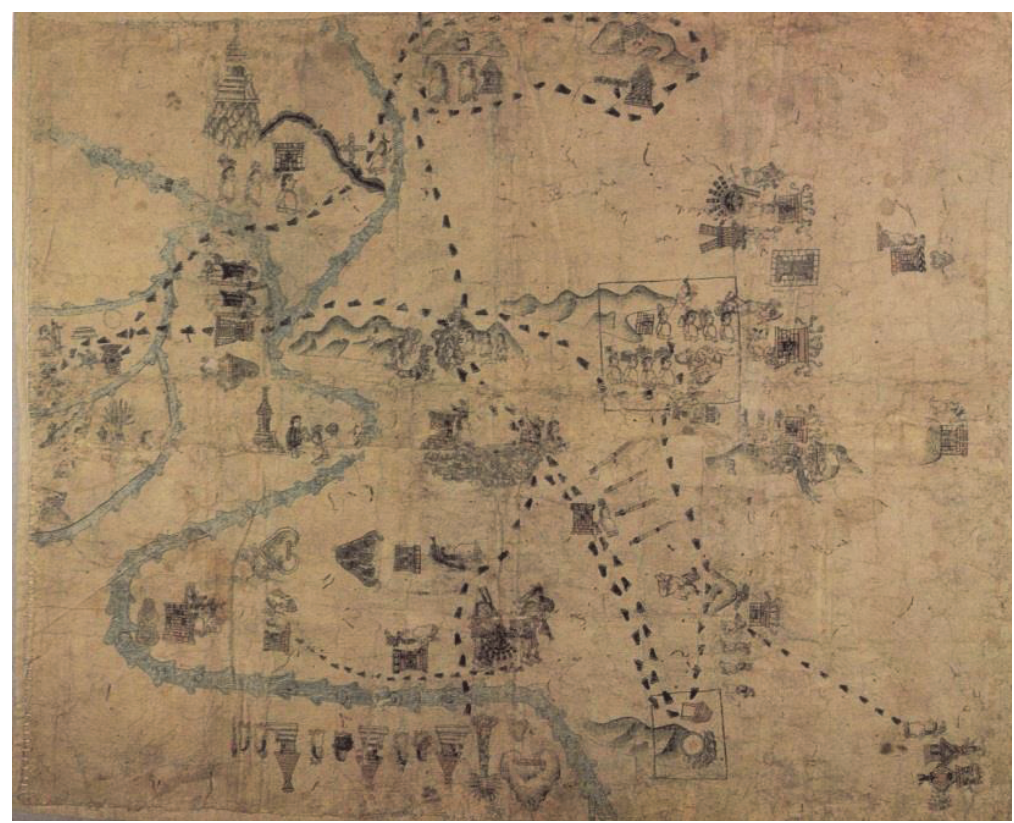

Figura 9. Mapa de las migraciones Uexotzinco-Tepeaca o Mapa de Cuauhtinchan, núm. 3, Yoneda Keiko, Los mapas de Cuauhtinchan y la historia cartográfica prehispánica, México, Fondo de Cultura Económica y Puebla, 1992, p. 141.

La corona española al anexar las nuevas extensiones comenzó a registrar el imperio. Solo de esta manera se podía establecer un control a través de los catastros que validaban la información a distancia y contenían el sistema social imperial. Para ello, se llevaron a cabo las Relaciones Geográficas en América conocidas como Relaciones Topográficas en Castilla. Si desde un comienzo la realeza trató de ordenar la sociedad a través del registro de sus propiedades y de sus súbditos, las memorias. Hay que tener en cuenta que en varias ocasiones - desde el punto de vista geográfico de la península - se contempló la generación de cartografía del reino, proyectos como: la Descripción y Cosmografía de Hernando Colón (Figura 8), el Atlas de El Escorial y el mapa del Maestro Esquivel, ${ }^{16}$ empresas que demostraban la importancia y el interés que representaba el conocer sus dominios, siendo la cartografía la ciencia que confería el imaginario global para la monarquía.

Las Relaciones Geográficas apuntaban a describir no solamente el espacio territorial, sino que también representaban la topología de las relaciones humanas. En ellas se incluían además, los conocimientos de los habitantes: los naturales. En sus

16 Antonio Crespo Sanz, "La descripción y cosmografía de España: el mapa que nunca existió", Revista Catastro, núm. 74, España (2012), p. 83. Disponible en: <http://www.catastro.meh.es/ documentos/publicaciones/ct/ct74/4.pdf> (consultada el 12 de abril de 2013). 
mapas representaban su territorio como su cosmovisión, siendo de gran ayuda tanto para el descubrimiento interior como para la conquista de los sectores aislados. Esta información viajaba periódicamente a Europa; los datos contenidos eran de gran ayuda si se deseaba seguir con la expansión territorial. Aunque muchos de ellos, ya tenían el sello de una aculturación ibérica, el distinguir las pictografías nativas con los elementos geográficos no fue una tarea pesada. ${ }^{17}$ Eso sí, los nativos también protegieron y resguardaron documentos que se prohibieron a los españoles, con el objetivo de no perder sus títulos de propiedad o evitar el pago del tributo, lo que llevó a más de un siglo volver a un contexto tradicional de los mapas nativos, para comprender el ocultamiento de información. ${ }^{18}$

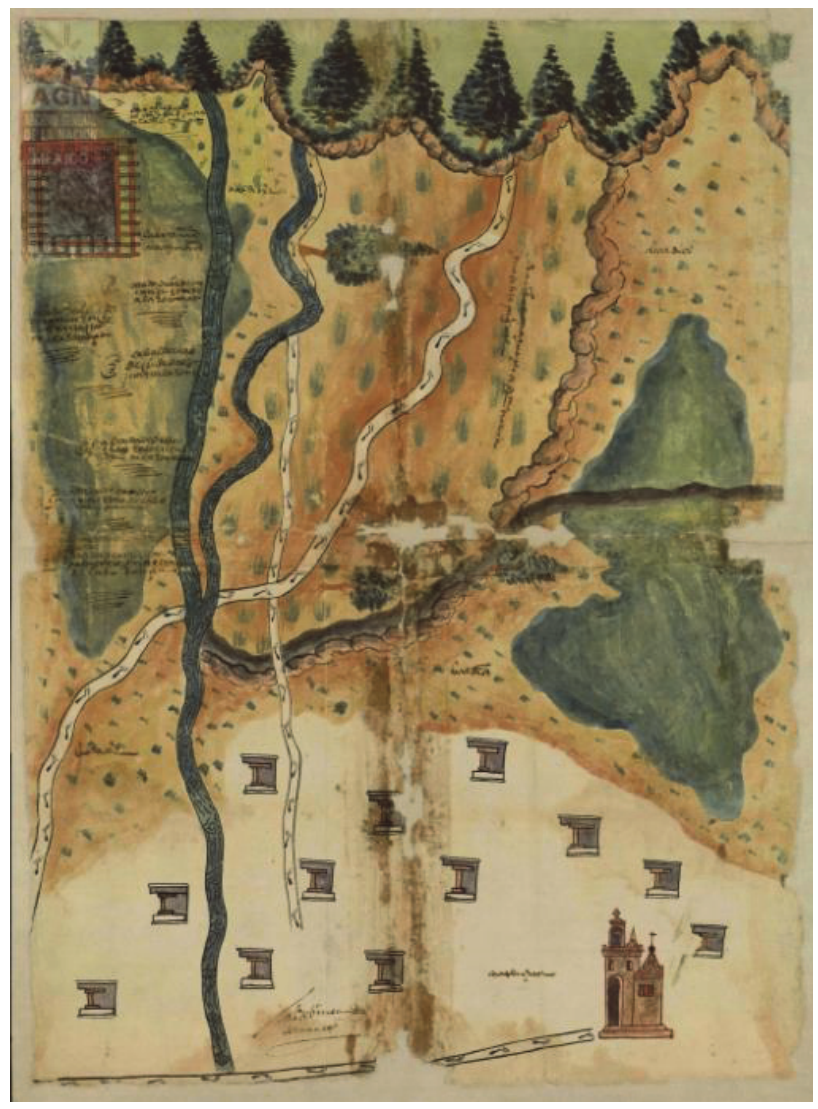

Figura 10. Mapas indígenas novohispanos (1578), Archivo General de la Nación.

17 Si bien, es difícil entender las imágenes de los nativos. Las expresiones espaciales son más globalizadas, lo que permite un entendimiento cultural general de los elementos geográficos comunes.

18 Serge Gruzinski, La Colonización de lo Imaginario. Sociedades indígenas y occidentalización en el México español. Siglos XVI-XVIII, México, Fondo de Cultura Económica, 1991, pp. 105-107. 


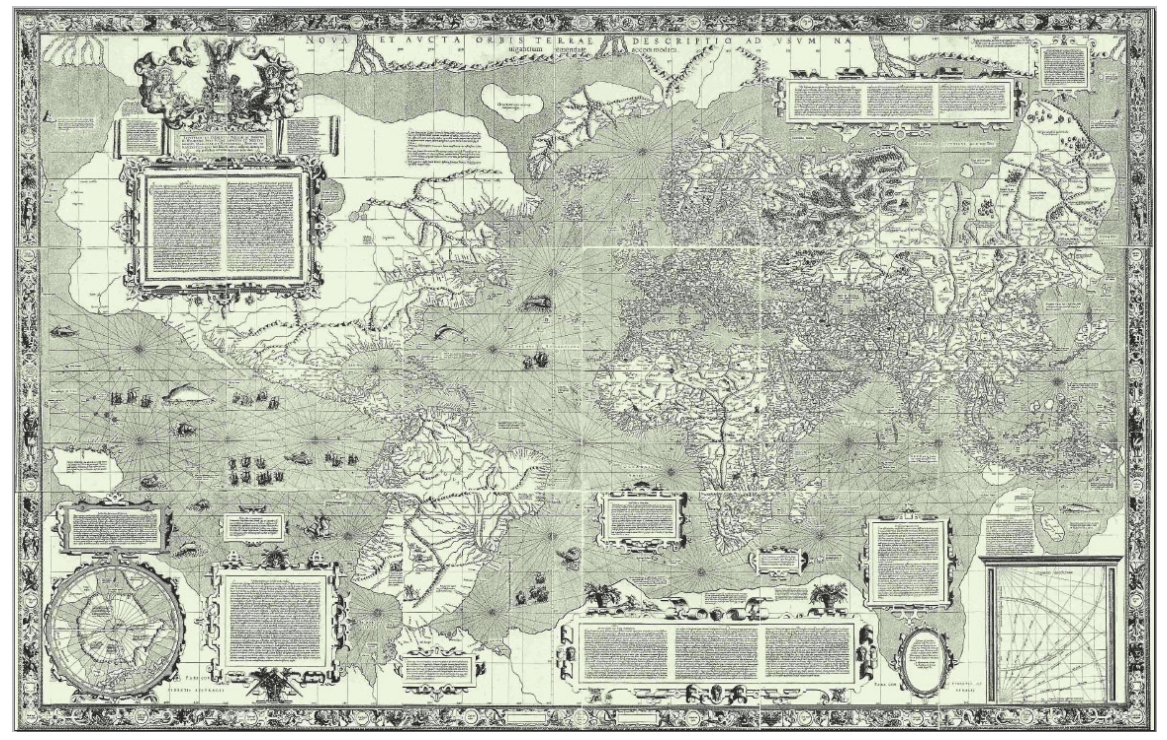

Figura 11. Gerardus Mercator, Carta do Mundo de Mercator (1569).

Si bien, para la Nueva España (México) el estudio cartográfico nativo se desarrolló de acuerdo con los parámetros europeos (Figuras 9 y 10), no hay que olvidar que la cosmovisión de culturas nativas del Nuevo Mundo se comparaban con la visión de algunos de los cosmógrafos europeos que identificaban el cosmos en su totalidad.

Las cadenas de mando que regían a la monarquía ibérica iba dada desde el rey a sus correspondientes virreyes, estos a su vez — al igual que los reyes —, se apoyaban en el asesoramiento y confesión de los clérigos, punto que la historiografía ha tratado como la contradicción potencial entre lo secular y lo clerical ${ }^{19}$ para mantener el orden y el control social. Adecuación que llevaron muy bien la orden de la Compañía de Jesús, que aconsejaban y tomaban cargos de directores hasta la participación prohibida en los negocios seglares. Tanto en las guerras como en los puntos de expansión de la corona, estos miembros utilizaban estrategias para alcanzar el poder, sin dejar de mencionar los intereses que preocupaban a los preceptos de la religión Católica Apostólica Romana, la guerra en contra de los protestantes, la herejía o las doctrinas liberales.

Cabe destacar entre ellos, la gran preparación que tenían, sobre todo como cosmógrafos y estudiosos de prestigiosas universidades, que influían en las decisiones de las cúpulas de poder: la elite gobernante. Desde los flancos hispanos y europeos 
hasta los mismos imperios del Japón y de China, ${ }^{20}$ los misioneros jugaron un papel muy importante en la expansión territorial del continente americano, los que interpretaban y generaban la mayor cantidad de mapas, algunos con información muy detallada como es el caso del mapa de Matteo Ricci (Figura 4), otros por el contrario, solo destinado a detalles específicos de ciudades, diferencias que se registran en decenas de mapamundis que incluían la cuarta parte del mundo: América.

Muchos son los ejemplos que se podrían dar sobre estos "consejeros reales", destacan entre ellos, la idea del padre Martín de Rada como del jesuita Alonso Sánchez de invadir el Imperio Chino, ${ }^{21}$ idea que no logró su objetivo y que podría haber acabado con la monarquía hispánica, siendo el propio Felipe II (1577), quien pusiera término a dicha aspiración.

\section{Hegemonía política y religiosa}

De acuerdo a los intereses expansionistas que se dieron en la corona, los mapas produjeron diferentes intenciones que llevaron a ocultar el territorio. Pero a pesar de ello, ocurrió otro hecho que en otra manera cambio el carácter superficial de América.

La gran cantidad de territorios de la monarquía ibérica, no solamente servían para pagar los tributos de sus súbditos, sino que sirvió para mostrar este nuevo orden y conquista mundial que se daba en las cuatro partes del mundo. Como señala Po-Chia, la alianza de intereses de la Corona con el Papado, y con ella las misiones, cumplían un papel crucial para expandir el territorio del rey católico, eran parte importante en dar a conocer la grandeza de su majestad y sobre todo de Dios, ${ }^{22}$ tratando de crear en el imaginario de los enemigos y de los vencidos la hegemonía política que representaba el imperio hispano. Es por ello que en varias ocasiones se utilizaron los mapas para demostrar ese potencial para intimidar al enemigo, punto que difiere del ocultar, sino más bien a engrandecer las posesiones ibéricas.

En las misiones a las Indias Orientales se juega con este instrumento: para Matteo Ricci mostrar al emperador un mapa en el cual China no era el centro del mundo, generó la elaboración y el diseño de un nuevo modelo que rompía con las

20 Entre los misioneros Jesuitas más importantes en las Indias Orientales (Japón y China) destacan: Matteo Ricci y Alessandro Valignano, sobre todo por utilizar una aculturación de la religión, lo que se designó con el nombre de accomodatio.

21 Carlos De la Vega, "Un proyecto utópico: La conquista de China por España", Boletín de la Asociación Española de Orientalistas, vol. XVIII, núm. 1, (1982), pp. 3-46. Disponible en: $\mathrm{http} / /$ digitool-uam.greendata.es/R/NXTQI2V3V4N88JVAGVTMXN7K8MBQKP1GNV77CDDH 16EMKS2GEN-00501?func=dbin-jump-full\&object_id=39067\&pds_handle=GUEST (consultada el 18 de mayo de 2013), también se puede revisar la tesis doctoral de Manuel Ollé, sobre la relación entre Alonso Sánchez y China en "La invención de China. Percepciones y estrategias filipinas respecto a China durante el siglo XVI".

22 R. Po-Chia Hsia, El mundo de la renovación católica, 1540-1770, Madrid, Ediciones Akal, 2010, pp. 235-254. 
tendencias occidentales, representando las riquezas y virtudes que tenía la Cuenca del Pacífico; ${ }^{23}$ en Japón antes de ser hundido el galeón español San Felipe su capitán trataba de impresionar a los funcionarios japoneses con un mapamundi de las conquistas españolas. ${ }^{24}$

En el círculo de la elaboración cartográfica se generaron diferentes modelos, cabe destacar dentro de los aportes a la disciplina la Proyección de Mercator - utilizada hasta nuestros días-, la cual aumentaba el tamaño de las superficies del norte en comparación con las del sur, quedando disminuidas África y América (Figura 11), apoyando así, el adoctrinamiento y la enseñanza que se impartía en las misiones. Este control social simbolizaba al mundo siguiendo la tendencia medieval de los mapas de $\mathrm{T}$ en $\mathrm{O}$, y conduce a imponer el cambio de orientación a la cercanía de Dios en lo de arriba, el norte.

La religión católica como sistema de estado se preocupaba de imponer ese dominio y predominio de sus adeptos y sus enemigos, para ello utilizó la censura que se atribuyó a la publicación y distribución de libros prohibidos. Aunque no se pudo hallar mayor información, solo el hecho de que algunos cartógrafos fueron acusados de herejía como el caso de Gerardo Mercator (1544), inclina a incluir dentro de las censuras éstas herramientas de representación: los mapas. Pero siguiendo el estilo de Harley sobre el secreto de los mapas, no debería ser para nada sospechoso que mucha cartografía anterior a los siglos estudiados fuera quemada o desaparecida para infundir un imaginario definido en la sociedad. Idea que no falló por completa, dando grandes frutos en la aculturación de los nativos que muy rápidamente se adaptaron a las ideas y concepciones hispánicas o mundialistas al tener un solo patrón de visualización dentro del adoctrinamiento que recibían en las escuelas.

Por último, solamente nombrar las reducciones que se dan en América a los diferentes nativos y a su forma de vivir. Reducciones que pasan a ser segregaciones residenciales, objetivos que se utilizan para la organización espacial y que responden a la planificación del territorio para mantener el sistema introducido. Si bien estas organizaciones del espacio nativo corresponden a planos más que a mapas, se interconectan por el diseño que debían ofrecer a la comunidad indígena permitiendo este medio de cohesión con el patriarcado monárquico.

\section{Conclusión}

El continente americano ha sido un espacio donde se conjugan diferentes intereses del Estado y comerciales. Como se pudo revisar en este artículo, la cartografía de

23 Este punto lo estudio dentro de las propuestas de cartografías históricas como apoyo al desarrollo y visión del territorio, trabajo que he realizado como: "Matteo Ricci y la Cuenca del Pacífico: Cartografía y Poder Político", Propuesta de Investigación Seminario Historia Universal, Magister en Historia, Universidad Nacional Andrés Bello (segundo semestre, 2012).

24 Po-Chia Hsia, 2010, p. 244. 
América jugó dentro de los factores que influyeron a ocultar y enaltecer el territorio. Como señala Harley la cartografía es información y el que tiene el conocimiento tiene el poder. ${ }^{25}$ Ese poder que debía ser legitimado llevó tanto a la Corona como al Papado a ocultar el Nuevo Mundo, por el peligro que ejercían tanto las otras monarquías, como a los adversarios (los protestantes y más adelante los comerciantes), y a engrandecerlo — punto contrario — según la ocasión.

El arte de elaborar un mapa — para occidente - estaba destinado a las clases gobernantes, quienes dependían de estos instrumentos para sacar provecho de las riquezas de la tierra conquistada, llevando a finalizar en conflictos de intereses tanto de los gobernantes como de los gobernados. La Monarquía sabía del peligro que representaban los mapas, acontecimientos que se daban a menudo por el contrabando de información y que de alguna manera recayó en la cartografía del Nuevo Mundo como espacios de poder que no podían perderse. Sin embargo, el ocultar este territorio no bastó para impedir las penetraciones de las otras coronas por las zonas norte y sur del continente.

Las coronas de Holanda e Inglaterra se fueron acercando cada vez más al centro de América, gracias a la utilización - por parte de los primeros - de las interpretaciones de las cartografías nativas y el gran ascenso en desarrollo de la ciencia cartográfica. Lo que llevó a la monarquía ibérica, nuevamente a engrandecer el continente, por sus dominios y conquistas en el Nuevo Mundo: el mundo de Felipe. ${ }^{26}$ Este nuevo concepto cambió el diseño y los ejes de representación de los mapas, los que utilizaron al nuevo continente como centro y abastecimiento para recorrer cada lado el planeta.

Para los sometidos de la Corona, los súbditos de este Nuevo Mundo, la América fue ilustrada como pequeña, el fin, lo de abajo. Siendo el occidente - sobre todo Europa - lo más cercano a Dios. Además de ello, el tener geográficamente en su localización tanto al Papado como al rey soberano de todo este mundo (cartografías a través de Proyección Mercator), influía a mirar a un solo sentido.

La doctrina que se suministró a través de las misiones fue en una cadena jerárquica que cumplía con el sistema de organización y control social. Se les daba esta educación a las elites nativas, los que transmitieron un nuevo imaginario de su entorno espacial. Este nuevo imaginario resultó en una disminución de los nativos en comparación con el blanco europeo, negatividad que infirió en una mirada hacia el blanqueamiento, una subordinación hacia el norte.

Al ser la cartografía la que moldea nuestra realidad espacial, el mapa fue el instrumento de representación para un público objetivo: los vencidos, los gobernados o súbditos, los enemigos. La incorporación del Nuevo Mundo reflejó una evo- 
lución en el pensamiento colectivo, cuarta parte o hemisferio oculto que engendraba la subordinación y el control de la sociedad.

\section{Bibliografía}

Bernand, Carmen y Gruzinski, Serge (1996). Historia del Nuevo Mundo: del descubrimiento a la conquista. La experiencia europea 1492-1550, Fondo de Cultura Económica, México.

Cabrera, Miguel (2008). "La situación de la historia tras la crisis de la modernidad. Desafíos teóricos y epistemológicos", en Seminario: Historiografía y tendencias en Historia Contemporánea: grandes maestros, nuevos valores, Universidad Internacional Menéndez Pelayo, España.

Carrera, Manuel (1968). "Las relaciones geográficas de Nueva España siglos XVI y XVIII”, en Estudios de historia novohispana, núm. 2, pp. 233-261.

Crespo Sanz, Antonio (2012). "La descripción y cosmografía de España: el mapa que nunca existió", Revista Catastro, núm. 74, España, pp. 83-109, <URL: http://www.catastro.meh.es/documentos/publicaciones/ct/ct74/4.pdf >.

De La Vega, Carlos (1982). "Un proyecto utópico: la conquista de China por España”, en Boletín de la Asociación Española de Orientalistas, vol. XVIII, núm. 1, pp. 3-46.

Espinoza, Jorge (1995). “Cartografía mental: una alternativa para la comprensión del comportamiento espacial del habitante urbano", en Revista Trilogía, vol. 23, núm. 24, Santiago de Chile.

García Roja, Irma (2008). "El estudio histórico de la cartografía”, en Takwa, núm. 13, pp. 11-32.

Gruzinski, Serge (1991). La Colonización de lo Imaginario. Sociedades indígenas y occidentalización en el México español. Siglos XVI-XVIII, Fondo de Cultura Económica, México.

- (2010). Las cuatro partes del mundo. Historia de una mundialización, Fondo de Cultura Económica, México.

Harley, J.B. (2005). La nueva naturaleza de los mapas ensayos sobre la historia de la cartografía, Fondo de Cultura Económica, México.

Hernando Rica, Agustín (2006). "La reforma de la mirada: logos y retórica en la Geographia de Ptolomeo (1535)", en Ería. Revista cuatrimestral de geografia, núm. 69, pp. 5-33.

Keiko, Yoneda (1992). Los mapas de Cuauhtinchan y la historia cartográfica prehispánica, Fondo de Cultura Económica, México.

Padron, Ricardo (2004). The Spacious Word: Cartography, Literature, and Empire in Early Modern Spain, University of Chicago, Chicago.

Po-Chia Hsia, R. (2007). "Disciplina social y catolicismo en la Europa de los siglos XVI y XVII”, en Manuscrits, núm. 25, España, pp. 29-43. 
(2010), El mundo de la renovación católica, 1540-1770, Ediciones Akal, Madrid.

Raisz, Erwin (1959). Cartografía general, trad. José Mantero, Omega, Barcelona. Taylor, Charles (2006). Imaginarios sociales modernos, trad. Vilà Vernis, Ediciones Paidós, Barcelona.

\section{Páginas WEB}

$<$ www.wikipedia.com $>$

$<$ www.bdmx.mx $>$ 